\title{
ROZWÓJ SEKTORA NOWOCZESNYCH USŁUG DLA BIZNESU W POLSCE
}

\author{
Marcin Kozak \\ Politechnika Częstochowska \\ Wydział Zarządzania
}

\begin{abstract}
Streszczenie: Artykuł przedstawia aktualny stan rozwoju sektora nowoczesnych usług dla biznesu w Polsce. Dokonano uporządkowania pojęć z zakresu offshoringu i outsourcingu usług, w tym usystematyzowano definicje centrów usług typu BPO (ang. Business Process Outsourcing) i SSC (ang. Shared Service Centre). Wskazano na główne korzyści dla lokalnej gospodarki w aglomeracjach miejskich wynikające z lokowania centrów usługowych w Polsce. Autor zaprezentował głównie wyniki badań realizowanych przez Związek Firm Liderów Sektora Usług Biznesowych (ABSL), a także raport z działalności Polskiej Agencji Informacji i Inwestycji Zagranicznych (PAIiIZ) w obszarze nowych projektów usługowych. W ostatniej części opracowania wskazano możliwe do uzyskania w Polsce zachęty inwestycyjne adresowane do firm z sektora nowoczesnych usług dla biznesu.
\end{abstract}

Słowa kluczowe: BPO, offshoring, outsourcing, SSC

DOI:10.17512/znpcz.2017.4.1.05

\section{Wprowadzenie}

Już od ponad 30 lat obserwujemy rozwój koncepcji outsourcingu i offshoringu usług biznesowych na świecie, choć aktualne rodzaje procesów biznesowych i modele biznesowe są zasadniczo różne od pierwszych modeli z lat 80 . i początku lat 90. ubiegłego wieku. Początkowo obsługiwane przez centra usług proste operacje typu call centers zostały rozwinięte w kierunku usług opartych na coraz większych zasobach wiedzy i wykonywane w coraz szerszej globalnej skali. Jako naturalny model zarządzania korporacją międzynarodową uznaje się ten, który przewiduje zewnętrzną obsługę procesów takich jak księgowość i płace, zakupy czy IT, niezależnie od lokalizacji zewnętrznego centrum usług na mapie świata. Rozwój sektora nowoczesnych usług biznesowych jest konsekwencją wdrażania nowych modeli biznesowych opartych na kluczowych kompetencjach. Wszystkie pozostałe procesy, nie niosące dla organizacji szczególnej wartości dodanej i nie będące źródłem przewagi konkurencyjnej, mogą zostać wyniesione poza strukturę organizacyjną. Taki model pozwala skupić cały wysiłek organizacyjny na rozwoju procesów decydujących w największym stopniu o przewadze rynkowej.

W okresie ostatnich 10 lat coraz większego znaczenia na globalnej mapie centrów usług biznesowych nabrały lokalizacje w krajach Europy Środkowo-Wschodniej, na czele z Polską. Mowa tutaj także o procesach o wysokiej wartości dodanej, opartych na profesjonalnej wiedzy eksperckiej, realizowanych w centrach badawczo-rozwojowych, które decydują o rozwoju nowych produktów. Kluczo- 
wym zagadnieniem z perspektywy krajów rozwijających się pozostaje wykorzystanie tej szansy i przełożenie tego potencjału na budowanie przewagi konkurencyjnej opartej na wiedzy i innowacjach, zamiast wciąż relatywnie niskich kosztach pracy. Dlatego tak ważne wydaje się skupienie jak największej liczby centrów nowoczesnych usług dla biznesu w polskich miastach, w szczególności centrów zaangażowanych w łańcuch kluczowych kompetencji innowacyjnych przedsiębiorstw.

Celem niniejszego opracowania jest przedstawienie dynamiki rozwoju i wpływu sektora nowoczesnych usług dla biznesu na wybrane obszary rozwoju społeczno-gospodarczego w Polsce. Poniższe opracowanie prezentuje stan rozwoju sektora usług dla biznesu w Polsce, liczbę i rodzaje centrów typu BPO (ang. Business Process Outsourcing), SSC (ang. Shared Service Centre), ITO (ang. Information Technology Outsourcing), KPO (ang. Knowledge Process Outsourcing). Zwrócono szczególną uwagę na znaczenie tego sektora dla generowania nowoczesnych miejsc pracy, stymulowania rynku nieruchomości biurowych, ale przede wszystkim dla konkurencyjności gospodarczej Polski na globalnym rynku inwestycji zagranicznych.

\section{Pojęcia ,outsourcing” i ,offshoring”}

Pojęcia „outsourcing” i „offshoring” są czasami błędnie używane zamiennie jako pojęcia tożsame. Należy przypomnieć, że są to różne procesy i dotyczą odpowiednio granic organizacji i krajów, mogą występować łącznie lub niezależnie od siebie.

Jak już na wstępnie wspomniano, koncepcja outsourcingu jest wynikiem zmieniających się modeli zarządzania przedsiębiorstwem, a jej wyjątkowo szybki rozwój, który rozpoczął się już w latach 90 . XX wieku, jest związany z pojawieniem się kolejnych nowych teorii w naukach o zarządzaniu, takich jak: kluczowe kompetencje (ang. core competencies), dynamiczne zdolności organizacji (ang. dynamic capabilities), ewolucyjna i zasobowa szkoła zarządzania przedsiębiorstwem. Dla rozwoju koncepcji outsourcingu nie bez znaczenia pozostaje także teoria ekonomiki kosztów transakcyjnych (ang. transaction cost economics). Niektórzy autorzy łączą także teorie analizy kosztów transakcyjnych i kluczowych kompetencji (Cox, Furlong 1997).

Głównym czynnikiem napędzającym rozwój outsourcingu i offshoringu było zmniejszanie się kosztów transakcyjnych. Przedsiębiorstwa podejmują decyzję o outsourcingu wybranych procesów i operacji w sytuacji, gdy zewnętrzny dostawca ma większe kompetencje w danym obszarze i jest bardziej efektywny kosztowo w ich realizacji. Wydzielając poza swoją strukturę mniej istotne procesy, przedsiębiorstwo skupia się na doskonaleniu kluczowych kompetencji zapewniających innowacyjność i przewagę konkurencyjną (Kim, Won 2007).

Powyższe szkoły i trendy w zarządzaniu stawiają kluczowe pytanie: dlaczego przedsiębiorstwo istnieje oraz czy i co powinno wytwarzać i kupować od zewnętrznych interesariuszy? Pojęcie kluczowych kompetencji odnosi się do najważniejszych zasobów wiedzy, które są źródłem trwałej przewagi konkurencyjnej organizacji (Prahalad, Hamel 1990). Z perspektywy zasobowej teorii przedsiębiorstwa kluczowe kompetencje oznaczają główne czynniki decydujące o innowa- 
cyjności i przewadze rynkowej przedsiębiorstwa. Zatem procesy i czynności niezwiązane bezpośrednio z kluczowymi kompetencjami mogą być zlecone na zewnątrz, bez uszczerbku dla rozwoju nowych produktów i utrzymania trwałej przewagi konkurencyjnej, w szczególności jeżeli te procesy mogą być wykonane taniej, szybciej i lepiej przez podmioty zewnętrzne.

Zatem w najprostszy sposób outsourcing można zdefiniować jako wydzielenie ze struktury organizacyjnej przedsiębiorstwa niektórych realizowanych samodzielnie funkcji i przekazanie ich do wykonania innym podmiotom (Trocki 2001, s. 13). Także definicja przyjęta przez UNCTAD (United Nations Conference on Trade and Development - organ pomocniczy Organizacji Narodów Zjednoczonych) zakłada, że gdy procesy są realizowane poza granicami organizacyjnymi przedsiębiorstwa, przez firmy działające w kraju klienta, jest to outsourcing. Natomiast gdy realizacja procesów odbywa się za granicą, takie rozwiązanie określa się mianem offshoringu (UNCTAD 2009).

$\mathrm{W}$ przeciwieństwie do outsourcingu offshoring odnosi się do macierzystego przedsiębiorstwa, które nabywa usługi lub przenosi część swojej działalności do innego przedsiębiorstwa spoza kraju macierzystego - może to być filia ustanowiona przez to przedsiębiorstwo w formie spółki powiązanej kapitałowo, wówczas mowa jest o tzw. captive offshoring lub international in-sourcing, lub inne niezależne kapitałowo przedsiębiorstwo, co określa się jako tzw. offshore outsourcing. Pierwszy z tych modeli umożliwia firmie pełną kontrolę nad przekazanymi operacjami i procesami produkcyjnymi lub usługowymi (Massini, Miozzon 2012, s. 1222). Jak zauważa Marcinkowska, można wprowadzić dodatkową klasyfikację offshoringu, przyjmując za kryterium podziału miejsce lokalizacji firmy offshoringowej. Mówimy wtedy o takich formach offshoringu jak: offshore, nearshoring i farshoring. Nearshoring oznacza współpracę firm na rynkach bliskich kulturowo i geograficznie. $\mathrm{Z}$ kolei offshore oznacza współpracę podmiotów na rynkach odległych w wymiarze geograficznym, ale bliskich w sensie kulturowym i ekonomicznym. Farshoring zakłada współpracę podmiotów odległych zarówno kulturowo i ekonomicznie, jak i geograficznie (Marcinkowska 2015).

W oparciu o dwie zmienne: własności zasobów i siedzibę dostawcy, można wyróżnić różne modele offshoringu (Tabela 1). Poza wymienionymi powyżej, modele mające charakter pośredni to: joint venture, virtual captive, build operate transfer. Joint venture jest stosunkowo nieskomplikowanym modelem offshoringu, natomiast dwa pozostałe mają charakter hybrydowy. Virtual captive łączy model oparty na własności (captive offshoring) oraz korzystaniu z wiedzy, doświadczenia i infrastruktury zewnętrznego dostawcy. W ramach modelu build operate transfer dostawca zewnętrzny buduje i zarządza centrum usług, aby po kilku latach dojrzałą jednostkę oddać klientowi (Szukalski 2012).

W początkowym okresie wprowadzania zmian organizacyjnych opartych na modelu offshoringu w przedsiębiorstwach międzynarodowych dotyczyły one głównie działalności produkcyjnej i powodowały napływ inwestycji zagranicznych do krajów słabiej rozwiniętych charakteryzujących się przewagą konkurencyjną w postaci niskich kosztów pracy. Pracochłonne etapy w łańcuchu produkcyjnym - początkowo 
w takich sektorach jak tekstylny, następnie w sektorach wysokich technologii, jak elektronika i motoryzacyjny - zostały przeniesione do krajów o niskich kosztach pracy.

Tabela 1. Klasyfikacja modeli outsourcingu i offshoringu

\begin{tabular}{|l|c|c|c|c|}
\hline \multirow{2}{*}{$\begin{array}{l}\text { Forma } \\
\text { własności }\end{array}$} & $\begin{array}{c}\text { Lokalizacja } \\
\text { bez zmian }\end{array}$ & $\begin{array}{c}\text { lokacja } \\
\text { za granicą } \\
\text { (rynki bliskie } \\
\text { geograficznie } \\
\text { i kulturowo) }\end{array}$ & $\begin{array}{c}\text { lokalizacja } \\
\text { za granica } \\
\text { (rynki odległe } \\
\text { geograficznie, } \\
\text { bliskie } \\
\text { kulturowo) }\end{array}$ & $\begin{array}{c}\text { lokalizacja } \\
\text { za granicą } \\
\text { (rynki odległe } \\
\text { geograficznie } \\
\text { i kulturowo) }\end{array}$ \\
\hline $\begin{array}{l}\text { Pełna } \\
\text { własność }\end{array}$ & status quo & $\begin{array}{c}\text { captive } \\
\text { nearshoring }\end{array}$ & $\begin{array}{c}\text { captive } \\
\text { offshoring }\end{array}$ & $\begin{array}{c}\text { captive } \\
\text { farshoring }\end{array}$ \\
\hline $\begin{array}{l}\text { Częściowa } \\
\text { własność }\end{array}$ & $\begin{array}{c}\text { joint venture } \\
\text { outsourcing }\end{array}$ & $\begin{array}{c}\text { joint venture } \\
\text { nearshoring } \\
\text { joint venture, } \\
\text { build operate } \\
\text { transfer, virtual } \\
\text { captive } \\
\text { offshoring }\end{array}$ & $\begin{array}{c}\text { joint venture, } \\
\text { build operate } \\
\text { transfer, virtual } \\
\text { captive } \\
\text { offshoring, } \\
\text { farshoring }\end{array}$ \\
\hline $\begin{array}{l}\text { Brak } \\
\text { własności }\end{array}$ & outsourcing & nearshoring & $\begin{array}{c}\text { offshore } \\
\text { outsourcing }\end{array}$ & $\begin{array}{c}\text { offshore } \\
\text { outsourcing }\end{array}$ \\
\hline
\end{tabular}

Źródło: (Rybiński 2007, za: Marcinkowska 2015)

Współczesny outsourcing i offshoring jest kolejnym etapem rozwoju powyższych trendów, ale przybiera dużo bardziej zaawansowaną formę i dotyczy procesów w dużo większym stopniu złożonych i bazujących na specjalistycznej wiedzy i nowych technologiach. Rozwój coraz bardziej zaawansowanych modeli outsourcingu $\mathrm{w}$ synergii $\mathrm{z}$ rozwojem nowych technologii, w szczególności $\mathrm{w}$ obszarze informatyki i komunikacji, przyczynił się do rozwoju nowego sektora w gospodarce, tzw. outsourcingu procesów biznesowych (ang. BPO - Business Process Outsourcing). Do tego sektora zaliczyć należy także centra usług wspólnych (ang. SSC - Shared Service Centres). Ekspansja międzynarodowa centrów usług jest wynikiem optymalizowania kosztów wybranych procesów biznesowych poprzez konsolidację w jednej lokalizacji operacji, które dotychczas były realizowane w wielu oddziałach przedsiębiorstwa. Procesy te najczęściej obejmują powtarzalne czynności realizowane wcześniej równolegle przez kilka jednostek organizacyjnych firmy, jak na przykład: księgowość, zakupy, zarządzanie obsługą klienta, obsługa wynagrodzeń. Poza czynnikiem kosztowym znaczenie ma tutaj także standaryzacja sposobu działania w wymiarze całego przedsiębiorstwa, co ma pozytywny wpływ na jakość i poziom wydajności pracy.

\section{Sektor nowoczesnych usług biznesowych w Polsce - stan aktualny i perspektywy rozwoju}

Sektor usług biznesowych należy uznać za jedną z wiodących gałęzi gospodarki w Polsce, a sam rynek krajowy to już bardzo dojrzała lokalizacja w skali globalnej. 
Dzięki wysokiej pozycji Polski w rankingach lokalizacji usług dla biznesu wciąż możemy liczyć na napływ nowych zagranicznych projektów inwestycyjnych, niosących już nie tyle wysokie nakłady inwestycyjne, co często zaawansowaną wiedzę, jak w przypadku ośrodków badawczo-rozwojowych globalnych korporacji. Wysoki stopień informatyzacji tego sektora pozwala na równoległe wdrożenia innowacyjnych rozwiązań we wszystkich dywizjach danej korporacji, stąd możliwość natychmiastowego transferu wiedzy także przez polskie oddziały centrów usług wspólnych. Warto odnotować coraz większy udział centrów usług z polskim kapitałem, co świadczy o realizowanych procesach uczenia się rodzimych podmiotów, ale również jest świadectwem wdrażania rozwiązań outsourcingowych przez polskie przedsiębiorstwa, a także, choć wciąż w niewielkim stopniu, przez podmioty publiczne. Pod względem liczby osób zatrudnionych sektor BPO/SSC wyprzedza wiele tradycyjnych branż gospodarki, jak choćby górnictwo, i może równać się $\mathrm{z}$ sektorem motoryzacyjnym. Rola sektora jest nie do przecenienia w wymiarze przede wszystkim rynku pracy i możliwości rozwoju gospodarczego w oparciu o usługi. Nowoczesne miejsca pracy o dużej wartości dodanej i ponadprzeciętne wynagrodzenia oznaczają realnie większą siłę nabywczą i budują klasę średnią głównie w miastach regionalnych, co jednoznacznie przekłada się na inne gałęzie lokalnej gospodarki, jak handel, gastronomia, „przemysł” czasu wolnego, budownictwo (mieszkania i powierzchnie biurowe). Specjaliści w najbardziej pożądanych branżach, jak informatyka oraz księgowość i finanse, znający języki obce, szczególnie inne niż popularny angielski, mogą liczyć na ponadprzeciętne wynagrodzenia i stabilną pracę w centrach usług biznesowych. Szacuje się, iż aktualnie w Polsce pracuje ponad 200 tys. osób w ponad 900 centrach usług dla biznesu. Warto przyjrzeć się strukturze tych ośrodków zarówno w wymiarze obsługiwanych procesów, profilu zatrudnionych kadr, jak i w ujęciu geograficznym. W sposób szczególny sektor usług dla biznesu oddziałuje na duże aglomeracje miejskie, które są skupiskiem centrów BPO/SSC, stąd też duży wysiłek samorządów w kierunku budowania konkurencyjnej pozycji celem przyciągnięcia nowych inwestycji i stworzenia wartościowych miejsc pracy.

W przedmiotowym opracowaniu źródłem danych statystycznych na temat sektora $\mathrm{BPO} / \mathrm{SSC} \mathrm{w}$ Polsce są dwa podstawowe ośrodki i przeprowadzone przez nie badania: Polska Agencja Informacji i Inwestycji Zagranicznych (PAIiIZ 2015) oraz Związek Liderów Sektora Usług Biznesowych (ABSL 2016). W ramach prezentacji posłużono się ogólnie przyjętym w powyższych opracowaniach podziałem sektora nowoczesnych usług dla biznesu na:

- centra usług wspólnych (SSC),

- centra outosourcingu procesów biznesowych (BPO),

- centra IT,

- centra badawczo-rozwojowe R\&D.

Raport ABSL przedstawia najbardziej precyzyjne dane na temat sektora nowoczesnych usług dla biznesu w Polsce na koniec pierwszego kwartału 2016 roku (ABSL 2016). Całkowite zatrudnienie w sektorze wynosiło 212 tys. osób, w tym 177 tys. osób w centrach zagranicznych. Swoje centra usług w Polsce posiadało 593 inwestorów, w tym 461 inwestorów zagranicznych, przy czym łączna liczba 
wynosiła 936 centrów, w tym 676 centrów zagranicznych. W Polsce funkcjonowało 37 centrów, w których zatrudnienie przekraczało tysiąc osób, i 7 ośrodków z zatrudnieniem powyżej 10 tys. osób. W okresie od pierwszego kwartału 2015 roku do pierwszego kwartału 2016 roku dynamika wzrostu zatrudnienia w sektorze wyniosła $25 \%$, a ABSL prognozuje osiągnięcie liczby 300 tys. osób zatrudnionych w 2020 roku. W rankingu Fortune Global 500 wśród pierwszych 100 firm jest 21 inwestorów obecnych w Polsce. Jeśli wziąć pod uwagę wszystkie ośrodki z kapitałem polskim i zagranicznym, pod względem zatrudnienia największy udział (34\%) w liczbie pracowników sektora generują centra usług wspólnych (SSC), następnie centra IT $(28 \%)$ odpowiedzialne m.in. za utrzymanie systemów, aplikacji, infrastruktury, wsparcie techniczne, wdrożenia oprogramowania. Udział centrów BPO wynosił $28 \%$, z kolei $15 \%$ przypada na centra R\&D. Warto odnotować, że dużo większy udział w strukturze zatrudnienia należy do centrów badawczo-rozwojowych z kapitałem zagranicznym $-17 \%$ osób zatrudnionych $w$ centrach $\mathrm{z}$ kapitałem zagranicznym w Polsce badanych przez ABSL to udział zatrudnienia wygenerowanego przez centra badawczo-rozwojowe, w porównaniu z 5-procentowym zatrudnieniem w grupie polskich centrów usług. Głównymi inwestorami, którzy generują to zatrudnienie, są firmy: Nokia, Intel, General Electric, Samsung, Motorola. Świadczy to o dużym potencjale intelektualnym i konkurencyjności kapitału ludzkiego w Polsce, w szczególności w dużych ośrodkach akademickich, co przyciąga inwestorów zagranicznych lokujących ośrodki badawczo-rozwojowe bazujące na wiedzy i innowacjach. W efekcie lokalizacji tego typu ośrodków w Polsce w coraz większym stopniu możemy mówić o odchodzeniu od modelu konkurencyjności niskich kosztów pracy przy wykonywaniu prostych czynności na rzecz modelu konkurencyjności międzynarodowej bazującym na przewadze opartej na kapitale intelektualnym. Pozwala to na transfer wiedzy z globalnych korporacji i przynosi efekty „rozlewania się wiedzy” w ujęciu geograficznym (efekty typu knowledge spillovers (ang.)). Rzecz w tym, aby coraz więcej centrów nowoczesnych usług lokowanych w Polsce realizowała czynności coraz bardziej zaawansowane, typu opracowywanie i wdrażanie oprogramowania, projektowanie systemów mechanicznych dla sektora motoryzacji, obsługa globalnych funduszy inwestycyjnych.

Na Rysunku 1 przedstawiono strukturę zatrudnienia w sektorze nowoczesnych usług dla biznesu w Polsce. Należy odnotować, że badanie ABSL, którego wyniki przywołano, obejmowało wyłącznie centra usług posługujące się językami obcymi, zatem nie uwzględnia ono centrów świadczących usługi wyłącznie w języku polskim. Średnie zatrudnienie w centrach usług w Polsce wynosi 227 osób, a mediana zatrudnienia wynosi 100 osób. Najwyższe średnie zatrudnienie ogółem charakteryzuje centra usług wspólnych, a najniższe - centra badawczo-rozwojowe i IT. 


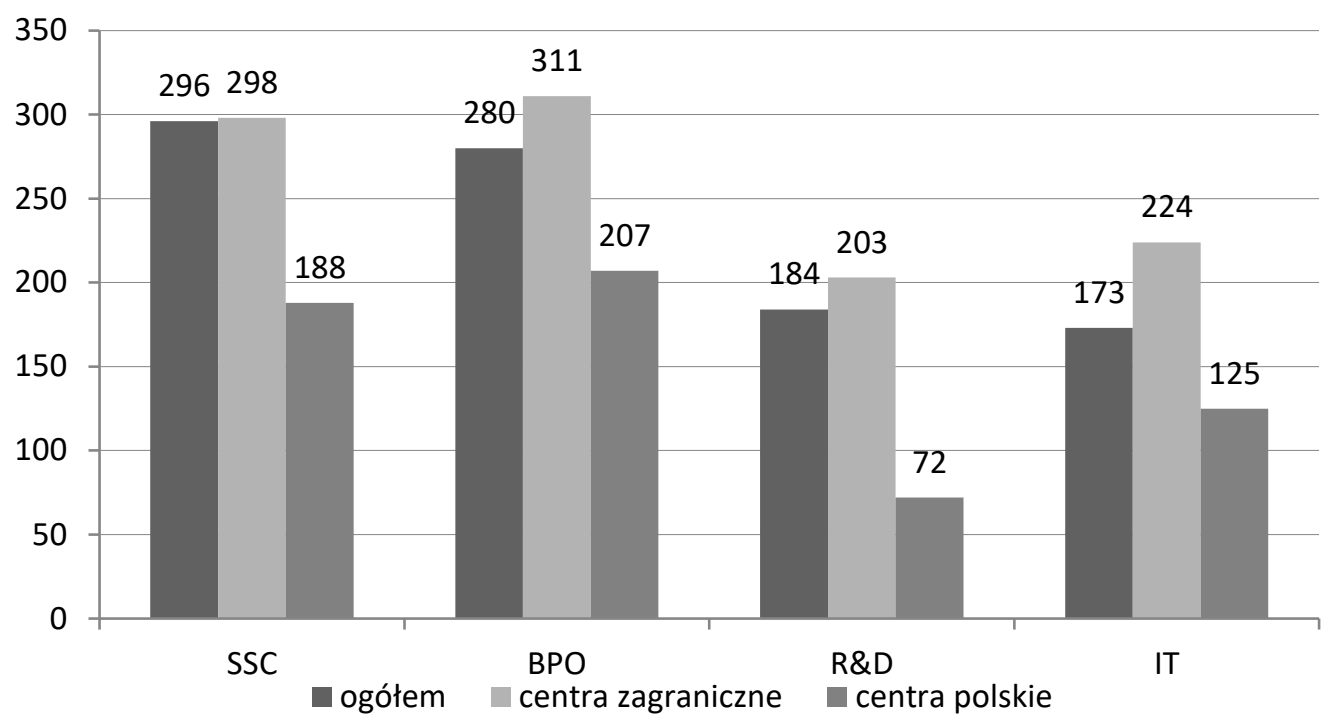

Rysunek 1. Przeciętne zatrudnienie w centrach BPO, SSC, IT, R\&D w podziale na centra polskie i zagraniczne $w 2016$ roku

Źródło: (ABSL 2016)

W ujęciu geograficznym centra nowoczesnych usług dla biznesu działaja w około 40 miastach w Polsce. Należy jednak odnotować bardzo dużą koncentrację centrów w kilku największych miastach akademickich. Ponad 85\% osób zatrudnionych pracuje w siedmiu głównych aglomeracjach miejskich: Kraków, Warszawa, Wrocław, Trójmiasto, Katowice, Łódź, Poznań. Pod względem przeciętnego zatrudnienia pozycja lidera należy do Krakowa, w którym przeciętne zatrudnienie w centrum usług wynosi 365 osób, co wynika gównie z obecności dużej liczby dużych inwestorów zatrudniających ponad 1000 osób. W znacznym stopniu lokalizację centrów usług w miastach determinują liczebność i dostępność wysoko wykwalifikowanej kadry ze znajomością języków obcych (przeciętne centrum usług w Polsce posługuje się średnio 8 językami obcymi), a w dalszej kolejności dostępność odpowiednio przygotowanej powierzchni biurowej czy też jakość infrastruktury komunikacyjnej. Powierzchnia biurowa jest w dużym stopniu pochodną rozwoju sektora nowoczesnych usług dla biznesu, który generuje znaczący popyt na nieruchomości biurowe. Według raportu ABSL w 2015 roku 54\% popytu na powierzchnie biurowe w Polsce poza Warszawą wygenerowały firmy z sektora usług dla biznesu. W odniesieniu do potencjału kadrowego danej lokalizacji regionalnej warto odnotować czynnik coraz większej konkurencyjności pomiędzy centrami w konkretnych lokalizacjach coraz bardziej nasyconych liczbą ulokowanych inwestorów. Kolejne decyzje lokalizacyjne nowych inwestorów wywołują większą rywalizację o kadrę między korporacjami i zwiększoną rotację pracowników. Według ABSL przeciętny wskaźnik rotacji pracowników $\mathrm{w}$ badanych centrach wynosił 15\% w 2015 roku. 
Centra usług obsługują różnorodne branże i procesy, większość z nich obsługuje kilka różnych procesów biznesowych. Na Rysunku 2 przedstawiono strukturę zatrudnienia w sektorze usług według kategorii obsługiwanych procesów. Według badania ABSL największy udział w strukturze zatrudnienia mają usługi informatyczne (37\% osób zatrudnionych). Usługi finansowo-księgowe wykonuje 19\% zatrudnionych, usługi finansowe, takie jak bankowość, ubezpieczenia, inwestycje, wygenerowały 11-procentowy udział $\mathrm{w}$ strukturze zatrudnienia $\mathrm{w}$ całym sektorze usług dla biznesu. Wyraźny udział mają także usługi kontaktu z klientem na poziomie $10 \%$ (ABSL 2016). Cztery powyższe branże generują prawie $80 \%$ zatrudnienia dla badanej próby centrów usług biznesowych.

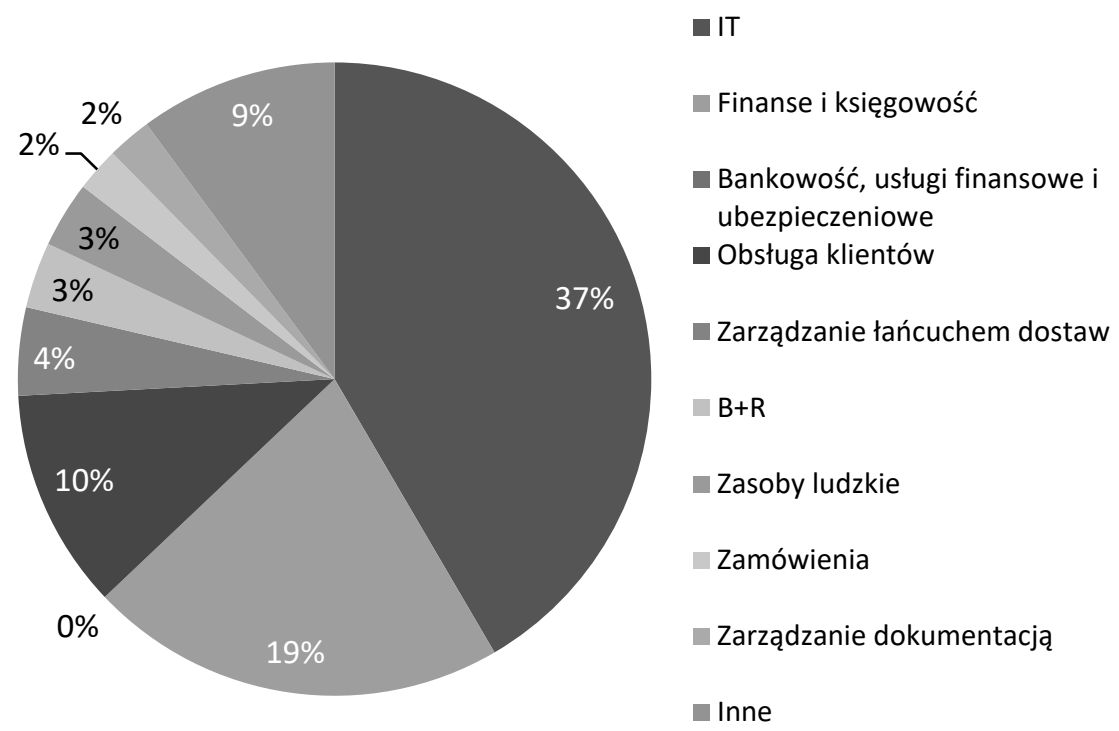

Rysunek 2. Struktura zatrudnienia $w$ centrach usług biznesowych wedlug obslugiwanych procesów

Źródło: (ABSL 2016)

Jak już wcześniej odnotowano, warto zwrócić uwagę także na pozytywny wpływ sektora nowoczesnych usług dla biznesu na inne branże gospodarki. Rozwój tego sektora wymusił wzrost podaży powierzchni biurowych w głównych ośrodkach regionalnych. Deweloperzy nieruchomości komercyjnych i firmy budowlane stały się częścią całego łańcucha powiązań z sektorem usług biznesowych, podobnie jak firmy rekrutacyjne i uczelnie. Wzorcowym przykładem włączenia uczelni w proces przygotowywania kadr dla sektora usług dla biznesu jest projekt ABSL Academy (http://abslacademy.pl), czyli kurs adresowany do osób planujących rozpocząc karierę zawodową w sektorze. Program kursu zawiera moduł realizowany przez uczelnie we współpracy z menedżerami wyższego szczebla reprezentującymi korporacje z sektora usług dla biznesu. 
Według przytaczanych powyżej raportów na temat sektora usług dla biznesu, w najbliższych kilku latach można przewidywać jego dalszy rozwój, zarówno pod względem liczby nowych miejsc pracy, jak i stopnia zaawansowania procesów obsługiwanych przez podmioty zlokalizowane w Polsce. Przewiduje się, że dynamika wzrostu poziomu zatrudnienia będzie zachowana podobnie jak w ostatnich dziesięciu latach, co oznacza, że do 2020 roku w sektorze może pracować łącznie nawet 300 tys. osób.

\section{Zachęty inwestycyjne dla sektora nowoczesnych usług dla biznesu}

Biorąc pod uwagę dużą wartość dodaną, jaką przynoszą lokalnej gospodarce nowe centra usług dla biznesu, w szczególności dobrze płatne miejsca pracy dla absolwentów szkół wyższych, tego typu projekty inwestycyjne stały się jednym z głównych celów Polskiej Agencji Informacji i Inwestycji Zagranicznych w ostatnich kilku latach (aktualnie Polska Agencja Inwestycji i Handlu). Stąd też starania rządów poszczególnych krajów o nowe projekty inwestycyjne i bogata paleta instrumentów wsparcia, jakie oferują inwestorom. Należy także zauważyć, że Polska pozostaje krajem bardzo konkurencyjnym dla inwestorów z tego sektora, między innymi z uwagi na wciąż liczne i konkurencyjne kosztowo zasoby kadrowe o odpowiednich kompetencjach. Polska jest tutaj liderem wśród krajów w Europie. Warto zatem wskazać na kilka instrumentów wsparcia, które często stają się decydujące dla nowych inwestorów lokujących nowe projekty właśnie w Polsce. W okresie ostatnich 10 lat odnotowano stały wzrost udziału projektów usługowych w liczbie nowych inwestycji lokowanych w Polsce. W latach 2004-2014 spośród 500 projektów inwestycyjnych 179 projektów dotyczyło sektora usług dla biznesu. Inwestorzy deklarowali utworzenie ponad 46 tys. nowych miejsc pracy. Z kolei w latach 2010 i 2011 wśród wszystkich deklarowanych przez inwestorów nowych miejsc pracy 57\% dotyczyło właśnie inwestycji w sektor usług dla biznesu (PAIiIZ 2015).

Jednym z instrumentów finansowych adresowanych do innowacyjnych przedsiębiorstw planujących nowe inwestycje, $\mathrm{w}$ tym $\mathrm{w}$ sektorze usług dla biznesu, był Program Innowacyjna Gospodarka realizowany w ramach okresu programowania Unii Europejskiej na lata 2007-2013. W ramach powyższego Programu na uwage zasługuje działanie 4.5 pod nazwą „Wsparcie inwestycji o dużym znaczeniu dla gospodarki” (PAIiIZ 2015), które za cel przyjęło poprawę konkurencyjności gospodarki poprzez zwiększenie liczby inwestycji o dużym potencjale innowacyjnym w sektorze nowoczesnych usług. W ramach Programu inwestorzy mogli otrzymać pomoc finansową $\mathrm{w}$ postaci dotacji na poziomie nawet do $70 \% \mathrm{w}$ przypadku projektów badawczo-rozwojowych, a w przypadku centrów usług wspólnych i centrów IT - do 30\% nakładów inwestycyjnych. Projekty z sektora usług dla biznesu stanowiły ponad $80 \%$ firm, z którymi zawarto umowy dotacji. Beneficjenci Programu zaoferowali utworzenie 12,7 tys. nowych miejsc pracy dla wysoko wykwalifikowanych pracowników. Przykładowy projekt, który otrzymał dotację o wartości blisko $13 \mathrm{mln}$ zł, to inwestycja w rozbudowę centrum usług wspólnych i utworzenie centrum kreatywności, innowacji i rozwoju przez firmę Global e-Business Operations. 
Z kolei w aktualnym okresie programowania 2014-2020 na uwage zasługuje Program Inteligentny Rozwój, z którego mogą korzystać także innowacyjne firmy z sektora nowoczesnych usług dla biznesu. Przykładowym instrumentem finansowym jest tutaj działanie 2.1 „Wsparcie inwestycji w infrastrukturę B+R”, które pozwala na uzyskanie dotacji na finansowanie kosztów utworzenia lub rozbudowy centrów badawczo-rozwojowych poprzez inwestycje w aparaturę, sprzęt i nowe technologie. Wydatki inwestycyjne mogą uzyskać pokrycie dotacją w wysokości nawet do $70 \%$, w zależności od ich charakteru i lokalizacji na mapie pomocy publicznej (www.funduszeeuropejskie.gov.pl).

Poza dotacjami na działalność badawczo-rozwojową sektor SSC może liczyć także na wsparcie w postaci ulg podatkowych oferowanych w ramach specjalnych stref ekonomicznych. Aktualnie w Polsce funkcjonuje 14 specjalnych stref ekonomicznych. Podobnie jak w innych krajach rozwijających się, także w Polsce specjalne strefy ekonomiczne pozostają główną zachętą dla bezpośrednich inwestycji zagranicznych. Okres obowiązywania zwolnień podatkowych w strefach ekonomicznych upływa w 2026 roku. Począwszy od 1 lipca 2014 r., zaczęły obowiązywać nowe, mniej korzystne z pespektywy inwestorów, limity regionalnej pomocy inwestycyjnej, w oparciu o które firmy otrzymują zezwolenia na działalność w strefach i zwolnienia z podatku dochodowego. W przypadku regionów bardziej rozwiniętych, a do takich zaliczono w Polsce 3 województwa: śląskie, wielkopolskie i dolnośląskie, limit regionalnej pomocy inwestycyjnej obniżono z $40 \%$ do $25 \%$, przy zachowaniu premii $10 \%$ i $20 \%$ odpowiednio dla średnich i małych firm. Powyższe zmiany miały wpływ zarówno na dynamikę napływu nowych projektów inwestycyjnych do stref jeszcze przed 30 czerwca 2014 r., ale także na wzrost znaczenia małych i średnich firm jako lokatorów stref objętych wciąż stosunkowo atrakcyjnym limitem zwolnienia podatkowego (Kozak 2015). Podstawę do kalkulacji pomocy publicznej $\mathrm{w}$ formie zwolnienia $\mathrm{z}$ podatku dochodowego stanowią koszty nowej inwestycji lub dwuletnie koszty nowych miejsc pracy zadeklarowanych przez inwestora. W przypadku firm z sektora usług dla biznesu właśnie możliwość uznania kosztów nowych miejsc pracy jako podstawy do kalkulacji pomocy publicznej może stanowić atrakcyjną zachętę podatkową do lokowania nowych centrów usług. $\mathrm{Na}$ terenach objętych statusem specjalnej strefy ekonomicznej w Polsce funkcjonują bowiem nieruchomości biurowe, których oferta jest dedykowana właśnie firmom z sektora usług dla biznesu. W efekcie nowy inwestor, lokalizując centrum usług na terenie takiej nieruchomości, może liczyć na uzyskanie zezwolenia na działalność w strefie ekonomicznej, które pozwala na zwolnienie z podatku dochodowego do wysokości limitu przysługującej pomocy publicznej w terminie do końca 2026 roku.

Warto odnotować także aktywność samorządów w obszarze zachęt inwestycyjnych adresowanych do firm z sektora nowoczesnych usług dla biznesu. Jako wzorcowy przykład można wskazać tutaj miasto Częstochowę, w którym przyjęto uchwałę Rady Miasta w sprawie programu pomocowego dla przedsiębiorców realizujących inwestycje w zakresie nowego budynku biurowego na potrzeby centrów usług wspólnych (Uchwała nr 118.XIII.2015...). Zwolnienie z podatku od nieruchomości przysługuje pod warunkiem powstania w wyniku inwestycji nowo wy- 
budowanego budynku o powierzchni użytkowej co najmniej $3000 \mathrm{~m}^{2}$, zajętego przynajmniej w $70 \%$ na działalność gospodarczą w branżach związanych z sektorem nowoczesnych usług dla biznesu. Zwolnienie ma zastosowanie, jeśli budynek spełnia obowiązkowe kryteria jakości przestrzeni biurowej i trzy z dodatkowych kryteriów standardów biurowych, w tym standard ochrony środowiska, przewidzianych dla klasy obiektu $\mathrm{B}+$, wynikających $\mathrm{z}$,Wytycznych do projektowania oraz opracowania specyfikacji współczesnych przestrzeni biurowych” Rolfe Judd Architecture. Przyjęcie tego typu programu pomocowego może mieć istotne znaczenie dla deweloperów niezdecydowanych co do realizacji nowoczesnego biurowca na zasadach inwestycji spekulacyjnej w ośrodku miejskim o stosunkowo niewielkiej sile nabywczej ze strony potencjalnych najemców. W efekcie miasto może przezwyciężyć tę barierę i uzyskać na swoim terenie powierzchnię biurową o standardzie odpowiadającym oczekiwaniom firm z sektora usług dla biznesu.

\section{Podsumowanie}

Jak wskazano powyżej, sektor nowoczesnych usług dla biznesu rozwija się w Polsce niezwykle dynamicznie w ostatnich 10 latach. Perspektywy zwiększenia zatrudnienia nawet do 300 tys. osób do 2020 roku są bardzo obiecujące i wywołują szczególną aktywność w branżach pokrewnych typu rynek nieruchomości biurowych. Należy jednak zwrócić uwagę na dwa kluczowe aspekty tak dynamicznego procesu rozwoju sektora w Polsce. Podstawowym wyzwaniem pozostaje gotowość ze strony Polski do zapewnienia odpowiedniej liczby kompetentnych zasobów kadrowych dla sektora. Już teraz bowiem wyraźnie widać coraz większą konkurencyjność $\mathrm{w}$ tym wymiarze pomiędzy centrami usług w głównych ośrodkach miejskich, co wywołuje presję płacową i tym samym w pewnym stopniu może przekładać się na mniejszą konkurencyjność centrów wobec lokalizacji w innych częściach Europy Wschodniej, np. w Bułgarii i w Rumunii. Drugim wyzwaniem jest konieczność dążenia do budowania przewagi konkurencyjnej polskich centrów w zakresie obsługi coraz bardziej zaawansowanych procesów biznesowych, w tym działalności badawczo-rozwojowej. Proste operacje, chociaż wykonywane w językach obcych, mogą zostać dużo łatwiej przeniesione do odległych lokalizacji o niższych kosztach pracy. $Z$ kolei centra usług oferujące bardziej zaawansowane procesy - typu obsługa ekspercka funduszy inwestycyjnych, programowanie, zaplecze $\mathrm{B}+\mathrm{R}$ dla międzynarodowej korporacji - są dużo bardziej pożądane i przynoszą znacznie większą wartość dodaną dla lokalnego rynku pracy i tym samym dla rozwoju lokalnej gospodarki.

\section{Literatura}

1. ABSL (2016), Sektor nowoczesnych ustug biznesowych w Polsce 2016, raport przygotowany przez Związek Liderów Sektora Usług Biznesowych (ABSL), www.absl.pl (dostęp: 01.03.2017).

2. Cox A., Furlong P. (1997), Cross-Border Trade and Contract Awards, „European Journal of Purchasing and Supply Management", Vol. 3, No. 1, s. 9-20. DOI: 10.1016/S09697012(96)00008-1 
3. http://abslacademy.pl (dostęp: 01.03.2017).

4. Kim G.M., Won H.J. (2007), HR BPO Service Models for Small and Medium Enterprises, „Business Process Management Journal”, Vol. 13, No. 5, s. 694-706. DOI: 10.1108/146371 50710823165

5. Kozak M. (2015), Znaczenie specjalnych stref ekonomicznych dla rozwoju regionalnego oraz sektora MŚP na przyktadzie miasta Częstochowy, [w:] Pachura A. (red.), Strategia glokalizacji w dziatalności sektora małych i średnich przedsiębiorstw, Wydawnictwo Wydziału Zarządzania Politechniki Częstochowskiej, Częstochowa, s. 59-73.

6. Marcinkowska E. (2015), Outsourcing i offshoring procesu rachunkowości-modele dostawy ushugi, „Prace Naukowe Uniwersytetu Ekonomicznego we Wrocławiu”, nr 399, s. 333-342. DOI: $10.15611 / p n .2015 .399 .32$

7. Massini S., Miozzon M. (2012), Outsourcing and Offshoring of Business Services: Challenges to Theory, Management and Geography of Innovation, „Regional Studies”, Vol. 46(9), s. 1219-1242. DOI: 10.2139/ssrn.1683467

8. PAliIZ (2015), 10 lat sektora nowoczesnych uslug biznesowych $w$ Polsce, Polska Agencja Informacji i Inwestycji Zagranicznych w Polsce, Warszawa, www.paih.gov.pl (dostęp: 01.03.2017).

9. Prahalad C.K., Hamel G. (1990), The Core Competences of the Corporation, „Harvard Business Review", May-June, s. 79-91.

10. Rybiński K. (2007), Globalizacja w trzech odstonach. Offshoring - globalne nierównowagi - polityka pieniężna, Difin, Warszawa.

11. Szukalski S. (2012), Procesowe i organizacyjne innowacje $w$ centrach ustug wspólnych, „Acta Universitatis Lodzensis. Folia Oeconomica”, nr 268, s. 107-123.

12. Trocki M. (2001), Outsourcing, PWE, Warszawa.

13. Uchwała nr 118.XIII.2015 Rady Miasta Częstochowy z dnia 2 lipca 2015 r., http://bip.czestochowa.pl

14. UNCTAD (2009), Information Economy Report. Trends and Outlook in Turbulent Times, United Nations Conference on Trade and Development, New York - Geneva.

15. www.funduszeeuropejskie.gov.pl (dostęp: 01.03.2017).

\section{DEVELOPMENT OF BUSINESS SERVICES SECTOR IN POLAND}

Abstract: The paper presents the condition of business services sector in Poland. The definitions of key terms offshoring and outsourcing have been introduced as well as the concept of BPO and SSC centres. The main advantages of establishing BPO and SSC centres in metropolitan areas were pointed out. The author presented the results of research conducted by ABSL and Polish Information and Investment Agency in the area of services sector in Poland. The last part of the paper shows the wide range of incentives addressed to new investment projects concerning business services sector.

Keywords: BPO, offshoring, outsourcing, SSC 